\title{
Nanosilver/poly (DL-lactic-co-glycolic acid) on titanium implant surfaces for the enhancement of antibacterial properties and osteoinductivity [Corrigendum]
}

\author{
Zeng X, Xiong S, Zhuo S, et al. Int $J$ Nanomed. \\ 2019;14:1849-1863.
}

Dr Zhong Zheng and Dr Kang Ting were not made aware of the manuscript prior to publication and did not meet our authorship criteria. They therefore need to be removed from the author list.

The final author list should therefore appear as:

Xuemin Zeng, ${ }^{1,2}$ Shijiang Xiong, ${ }^{1,3}$ Shaoyang Zhuo, ${ }^{1,4}$ Chunpeng Liu, ${ }^{1,2}$ Jie Miao, ${ }^{5}$ Dongxu Liu, ${ }^{1,2}$ Hengxiao Wang, ${ }^{6}$ Yueying Zhang, ${ }^{6}$ Chunling Wang, ${ }^{1,2}$ Yi Liu $^{1,2}$
${ }^{1}$ Shandong Provincial Key Laboratory of Oral Tissue Regeneration, School of Stomatology, Shandong University, Jinan, People's Republic of China; ${ }^{2}$ Department of Orthodontics, School of Stomatology, Shandong University, Jinan, People's Republic of China; ${ }^{3}$ Department of Endodontics, School of Stomatology, Shandong University, Jinan, People's Republic of China; ${ }^{4}$ Department of Oral Maxillofacial Surgery, School of Stomatology, Shandong University, Jinan, People's Republic of China; ${ }^{5}$ Department of Stomatology, The 5th People's Hospital of Jinan, Jinan, People's Republic of China; ${ }^{6}$ Department of Experimental Pathology, Institute of Basic Medicine, Shandong Academy of Medical Sciences, Jinan, People's Republic of China

\section{Publish your work in this journal}

The International Journal of Nanomedicine is an international, peerreviewed journal focusing on the application of nanotechnology in diagnostics, therapeutics, and drug delivery systems throughout the biomedical field. This journal is indexed on PubMed Central, MedLine, CAS, SciSearch $₫$, Current Contents $₫ /$ Clinical Medicine,
Journal Citation Reports/Science Edition, EMBase, Scopus and the Elsevier Bibliographic databases. The manuscript management system is completely online and includes a very quick and fair peer-review system, which is all easy to use. Visit http://www.dovepress.com/ testimonials.php to read real quotes from published authors. 